\title{
Neural network modeling of Herglotz-Wiechert inversion of multiparametric travel-time curves of seismic waves
}

\author{
(C) M. Lazarenko, O. Herasymenko, 2017
}

\author{
Institute of Geophysics, National Academy of Sciences of Ukraine, Kiev, Ukraine \\ Received 2 February 2017
}

\begin{abstract}
Використання мереж штучних нейронів у задачі побудови годографів сейсмічних хвиль дає змогу створювати нелінійні моделі поля часів поширення P - i S-фраз сейсмічних хвиль як функцій декількох аргументів: глибини розміщення вогнища, магнітуди, азимуту надходження хвиль і епіцентральної відстані. Побудову тривимірних годографів розглянуто на прикладах сейсмічних записів українських сейсмостанцій і їх використання для моделювання годографрів та інверсії останніх. Наведено приклади інверсії годографа в рамках моделі ГерглотцаВіхерта, а також особливості застосування моделі в реальному середовищі для одиничних сейсмостанцій і узагальнення для випадку довільних координат джерела і точки реєстрації сигналу в Чорноморському регіоні.

Ключові слова: нейронна мережа, поширення сейсмічних хвиль, навчання, інверсія Герглотца-Віхерта, розбіжності, годографи, градієнт швидкості.
\end{abstract}

Herglotz - Wiechert inversion of the travel-time curves of seismic waves, recorded by the network of seismic stations, generated by 4 -dimentional model. The number of recorded events with reliably defined arrivals of the phases of seismic waves are 392 for the seismic station (s/s) «Skvira», 501 for s/s "Odessa», and 371 for s/s «Poltava». Each seismic event, recorded at stations "Odessa», «Skvira» and "Poltava», was characterized by the following vector of parameters

$$
x_{n, i}=\left(x_{n, 1}, x_{n, 2}, \ldots, x_{n, 4}, t_{n}\right) \text {, }
$$

where $x_{1}=h$ (focal depth), $x_{2}=M$ (magnitude), $x_{3}=r$ (distance), $x_{4}=b \_a z$ (back azimuth), $t_{n}$ is a target value, which is equal to the arrival time to the observation point of a certain phase of the wave, generated by the $n$-th earthquake [Лазаренко, Герасименко, 2010].

The set of vectors for each seismic station was used as a training layered, fully connected, strait-line, managed network of artificial neurons model travel-time curve at three seismic stations with the parameters listed in SET1.

A set of such vectors for each seismic station was used as a learning set for a direct flow, multilayered, fully connected, controlled network of artificial neurons [Хайкин, 2008], using for learning a method the backward transmission of errors in neural networks [Chauvin, Rumelhart, 1995], while a sigmoid function in the form of a hyperbolic tangent was used as an activation function (Fig. 1).

In view of the mentioned above, the connectionist model of a seismic wave propagation time was designed as a combination of

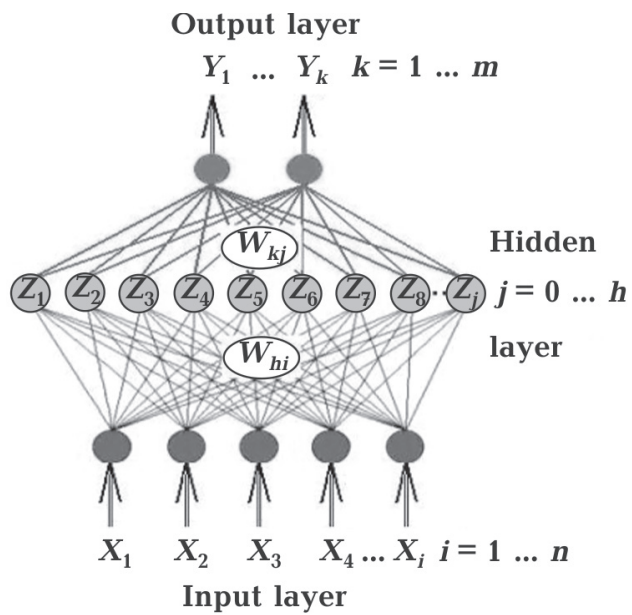

Fig. 1. Schematic diagram of a three-layer network of artificial neurons. 
nonlinear outputs (in notation of Fig. 1) of nodes $h$ of the hidden layer

$$
y_{k}=f_{k}\left(\sum_{j=1}^{h} \mathbf{w}_{k j} \mathbf{z}_{j}+\mathbf{w} b_{k}\right),
$$

where

$$
z_{j}=f_{j}\left(\sum_{i=1}^{n} \mathbf{w}_{h i} \mathbf{x}_{i}+\mathbf{w} b_{h}\right)
$$

and $f_{i}(\bullet)$ is the function of firing a neuron.

Thus a set is formed to learn the network of artificial neurons. After learning the latter forms the recording model for the seismic wave phases relating to the specific seismic station and the area the learning set relates to.
In the real-time mode, this model enables to forecast the s/s arrival time of a seismic wave, generated at a random point of the simulated area, with the source parameters within the range of the existence intervals of the vector components of the learning set.

The domain within the northern latitude, $\phi$, and the eastern longitude, $\lambda$, ranges from 50 to $36^{\circ}$ and 25 to $42^{\circ}$, respectively, was chosen for the modelling of the travel-time curves of $P$ - and $S$-seismic waves. In the selected region, «fields», controlled seismic stations «Skvira» and "Poltava», have dimensions of 1250-

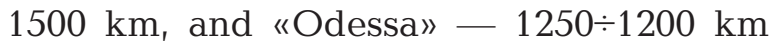
(Fig. 2).

The learning of the travel-time curve NN

\begin{tabular}{|c|c|c|c|c|c|c|c|c|c|c|}
\hline \multirow{2}{*}{$\begin{array}{l}\text { Seismic } \\
\text { Event } \\
\text { Station }\end{array}$} & \multirow{2}{*}{$\begin{array}{l}\text { Total } \\
\text { Events }\end{array}$} & \multirow{2}{*}{\begin{tabular}{|c|}
$\begin{array}{c}\text { Coefficient of } \\
\text { learning speed }\end{array}$ \\
от $2,5 \times 10^{-1}$ \\
\end{tabular}} & \multicolumn{2}{|c|}{ Learned $\times 10^{-1}$} & \multicolumn{2}{|c|}{$<5 \%$} & \multicolumn{2}{|c|}{$\begin{array}{l}\text { Specific } \\
\text { error, s }\end{array}$} & \multicolumn{2}{|c|}{$\begin{array}{c}\text { Standard } \\
\text { deviation, s }\end{array}$} \\
\hline & & & $\mathrm{P}$ & $\mathrm{S}$ & $\mathrm{P}$ & $\mathrm{S}$ & $\mathrm{P}$ & $\mathrm{S}$ & $\mathrm{P}$ & S \\
\hline Skvira & $392 / 359$ & Ао $\sim 4,0 \times 10^{-5}$ & 6,8 & 4,3 & 13 & 10 & 3,7 & 2,6 & 2,6 & 1,7 \\
\hline Odessa & $501 / 483$ & Aо $\sim 2,5 \times 10^{-5}$ & 6,6 & 4,9 & 27 & 15 & 3,2 & 2,8 & 1,6 & 2,1 \\
\hline Poltava & $371 / 357$ & до $\sim 6,0 \times 10^{-4}$ & 7,7 & 6,1 & 10 & 8 & 3,2 & 2,6 & 3,2 & 2,6 \\
\hline
\end{tabular}

Ta b l e. Parameters used in the NN learning=4: 20: 7: 2: 1

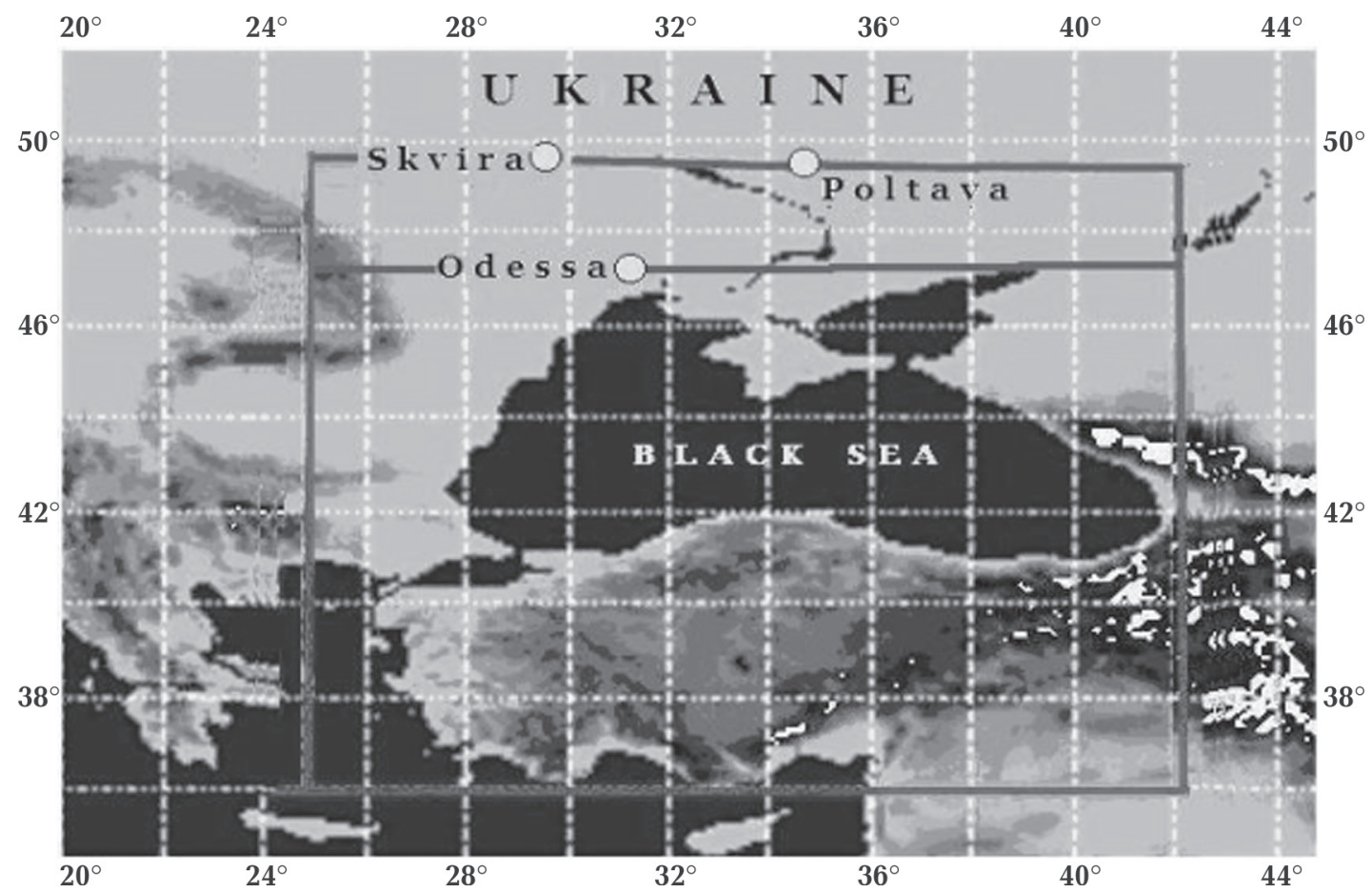

Fig. 2. Map of the region of research. 
model for these seismic stations was studied with the parameters, shown in Table. The learning was carried out in the stochastic mode with a hyperbolic tangent as the activation function for all the hidden words, excluding the output one, for which a unit (linear) function was used. The learning samples include the events, falling within the epicentral distance range of $2000 \mathrm{~km}$ for each seismic station. The number of these events in the table after a slash is shown. The normalization of input data was carried out for the mean range, as well as for the range equal to 0 , and the range equal to 2 .

The learning was carried out in the interactive mode, opening the access to the global parameters of learning after the execution of some (controlled) number of the iterations or epochs, referred to as "silent» epochs. The learning level of the model was estimated by the number of the members of the learning sample, for which the mis-tie between the output of the network and the size of its target value exceeded $5 \%$ of the latter, which matches the value of the characteristic function $\varphi=1$.

$$
\varphi(y)=\left\{\begin{array}{l}
1, \text { if }\left|y^{p}{ }_{k}-t^{p}\right| \leq \varepsilon \\
0, \text { not }
\end{array} .\right.
$$

Here $y_{k}^{p}$ is the network output, exited by $p$-th member of the training sample, $t^{p}$ is a target value, $\varepsilon=560 \times 10^{-3} t^{p}$. The process control of the training was based on rating the behaviour of the loss function, a specific error of miss-ties in the subset of the members of the training sample, not meeting the term $\varphi(y)=1$.

The residual value in the subset of «unpermitted» members of the training sample is usually distributed uniformly. Any deviations from such uniformity are usually caused by accidental errors, introduced at the stages of collection, primary processing and different types of manipulating the seismic data.

The neural network model of the 4-dimensional field of the arrival times of the seismic wave phases to the observation point enables the generation of travel-time curves for a random azimuth within the plane of the area under study. It is known that in the case of the medium, having a horizontal zero gradient of the propagation velocity of elastic waves and a non-decreasing gradient with depth, the inverse problem for a time curve has a Herglotz-Wiechert (H-W) unique solution and is written in the Abel form:

$$
z(x)=\frac{1}{\pi} \int_{0}^{x} \ln \left(k+\sqrt{k^{2}-1}\right) d x
$$

where $k=\frac{(\partial x / \partial t)_{x}}{x / t}, x-$ is the distance to the point of a ray exit to the earth surface, $t$ - is the time at an exit point and

$$
v[z(x)]=(d x / d t)_{x}
$$

is the phase velocity at the point of the maximum immersion of a ray in the medium.

For any length of the hodograph, simulated along the path, drawn from a seismic station through a random node of the region, the estimates of the maximum depth of the ray penetration and phase velocity at this depth may be obtained. Actually, these estimates are obtained for a certain infinitely thin plate, along the upper edge of which the path
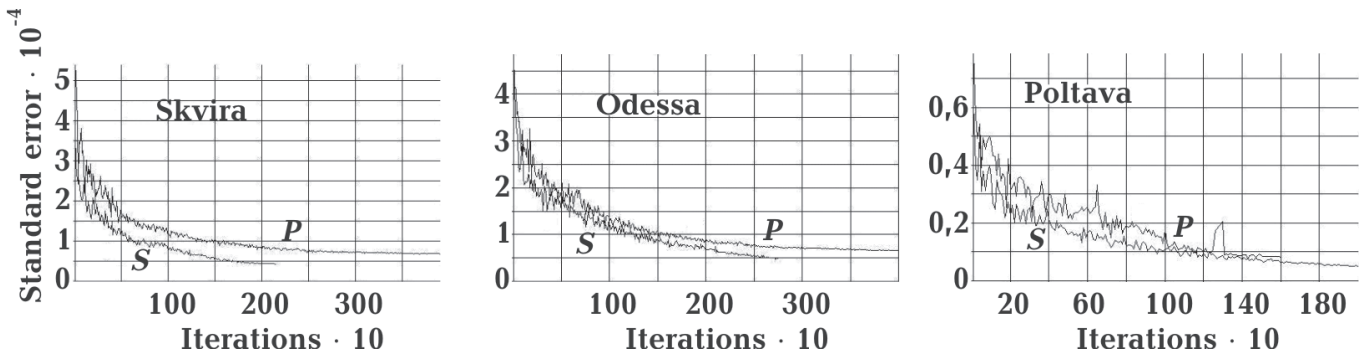

Fig. 3. The behaviour of the loss function depending on the number of iterations in training the NS models of the arrival times of the P and S phases of seismic waves to seismic stations «Skvira», «Odessa», «Poltava». 


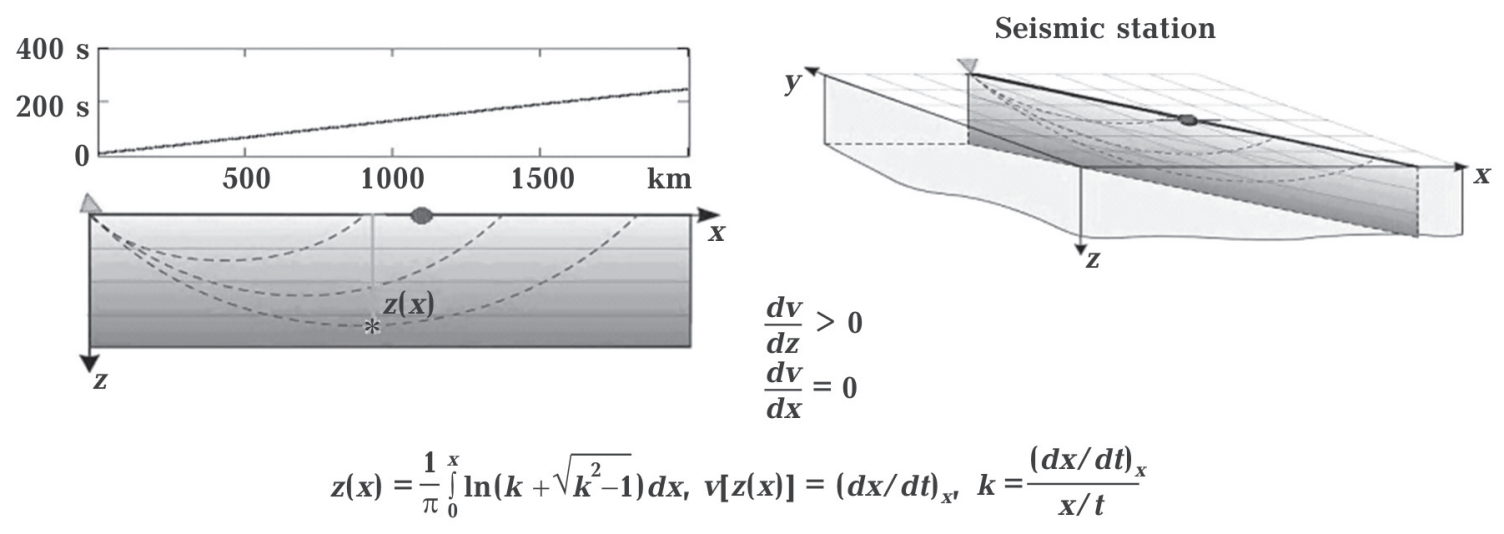

Fig. 4. The ray penetration depth and the phase velocity at the depth.

under consideration lies [Lay, Wallace, 1995].

Since, by the definition, the seismic velocity is independent of the horizontal coordinate, all the estimates of the velocities and the depths may be attributed to a random position along the path, say, a net node, and written in the form of two sequences: depths and the velocities matching these depths. It is evident that such two vectors may be obtained for each net node, and the distribution of phase velocities may be built by interpolation within the bounds of the net region from a certain range of depths.

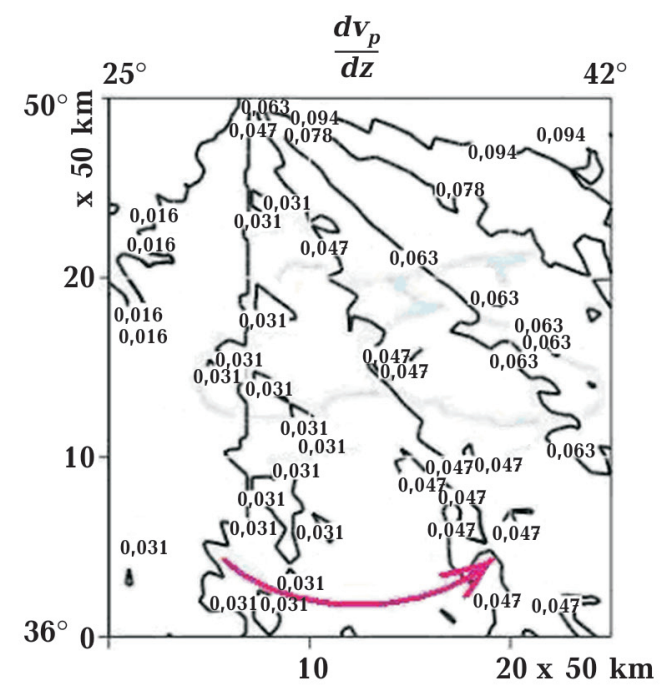

As it was previously noted, the solutions (5) and (6) allow to find the values of the maximum depths of the ray penetration and the velocities matching them at the nodes of the net covering the region (Fig. 4) and to estimate the velocity at any point within the depth range studied.

The survey sheets of the three seismic stations are net regions with a spacing of nodes longitudinally ( $x$ ) and latitudinally $(y)$, equal to $50 \mathrm{~km}$.

The seismic stations are placed at the upper edge of the survey sheets (see Fig. 4),

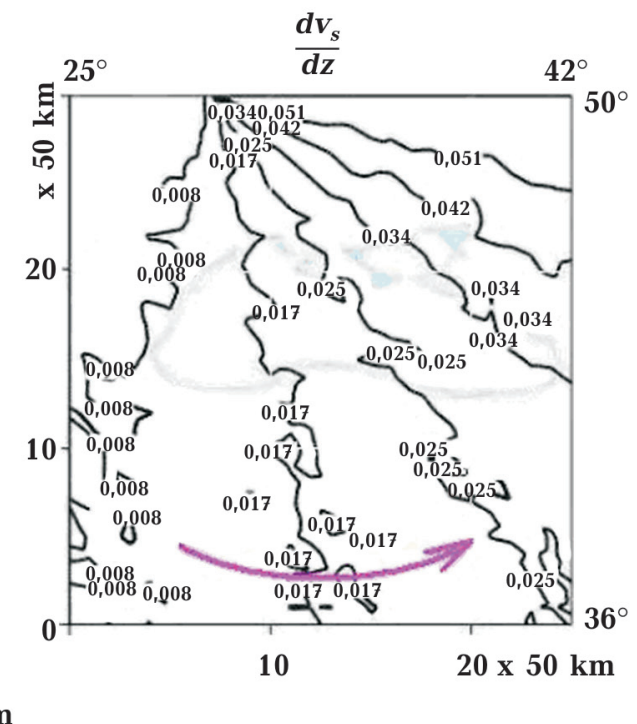

Fig. 5. Contour diagrams of the velocity gradients of the $\mathrm{P}$ and $\mathrm{S}$ seismic waves at the depth of $50 \mathrm{~km}$, obtained as result of inverting the time curves, generated by the connectionist model of the arrival times of the phases, recorded at s/s «Skvira». 
and for each of them the H-W inversion of the travel time of the $\mathrm{P}$ and $\mathrm{S}$ seismic waves was carried out for the simulated travel-time curves.

It is more convenient to represent the three-dimensional images of the velocity vectors of seismic waves in the form of their gradients, as it is shown in Fig. 5 for three seismic stations at the depth of $50 \mathrm{~km}$.

The estimatees of the velocities at nodal points of the net, carried out under the "fanning» scheme, do not consider the variations in the velocity along the path but rather simulate only the dependence of the wave arrival on the direction due to the velocity variation between the paths. It is evident that the path spacing, controlled by the density of the net, determines the discreteness of this quasi three-dimensional image.

The dependence of the maximum depths of the ray penetration on the length of a travel-time curve may be used to estimate a deep structure of the geological medium beneath the studied area.

It is clear that the plotting of the time curves for separate seismic stations, using a generalising (4-dimentional) approach, although extends the assortment of the studied characteristics of the propagation medium of seismic waves in comparison with the traditional approach, using a 1-dimensional time curve, but narrows its application, enabling the reception of only gradient estimates (Fig. 5) of the phase velocities of seismic waves at the depths, which are limited by the stationarity of the behaviour depending on the maximum depth of the ray penetration from the epicentric distance.

Under the similar scheme of representing the gradient of the velocity, based on simulating of the seismic wave arrival times to all the nodes of the net, we get the estimates of the gradient in the form of the projection on the direction (see Fig. 5).

The interpolation of nodal estimates enables to develop 3D images. To illustrate, in Fig. 5 the contour diagrams of the velocity gradients of the $\mathrm{P}$ and $\mathrm{S}$ seismic waves are shown for a depth of $50 \mathrm{~km}$. Variation of the direction of the velocity gradient recorded at different stations reflects the peculiarity of the movements of another nature prevailing in the formation process of the tectonic structures of a various origin. It was taken into account in choosing the location of the seismic stations within the territory of Ukraine. The configuration of the seismic net was developed not only to study the seismic activity between and inside the platforms, but also to study the intensity of distribution of the impact from the Vrancea earthquakes in the south-west and central Ukraine.

It is evident that the connectionist models for the seismic stations, located, for example, on the boundaries of a certain net region, will generate the time curves of the H-W inversion, which allow to estimate the projection of the velocity gradient in "their» direction, i. e., the tangents to the circle of the s/s-node radius. Whereas it is easy to recover the vector by its components.

Herglotz-Wiechert inversion of the travel-time curves generated by the 9-dimensional model. In plotting the local time curves for a seismic station, the coordinates of the latter are not the information parameters. For all example vectors of the behaviour of the time function of the phase arrival, they are single, and the position of the epicentre is unambiguously determined by the vector components: epicentric distance and azimuth. Whereas the development of a generalized model for a certain region assumes the compilation of the training sample within a wide range of the epicentric distance, containing the examples of the events, exited not only in a lot of sources, but also recorded in a lot of seismic stations.

Such an approach is directed towards ensuring the coverage by the propagation paths of the signals from the area involved with the uniformity as large as possible, and assuming the presence of seismic anisotropy. In this case, the position of the epicentre is not unambiguously determined by an epicentric distance and azimuth any longer, and should be set in the explicit form. Therefore, the dimension of the vector (1) increases to $N=9$, where $x$ is an elevation of the seismic station above sea level. 


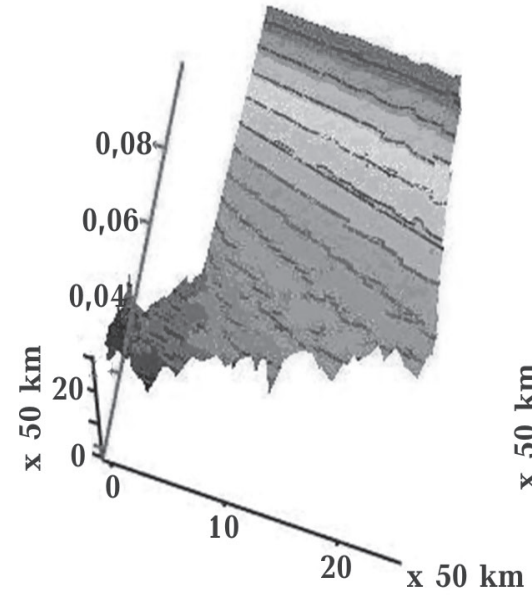

$50 \mathrm{~km}$

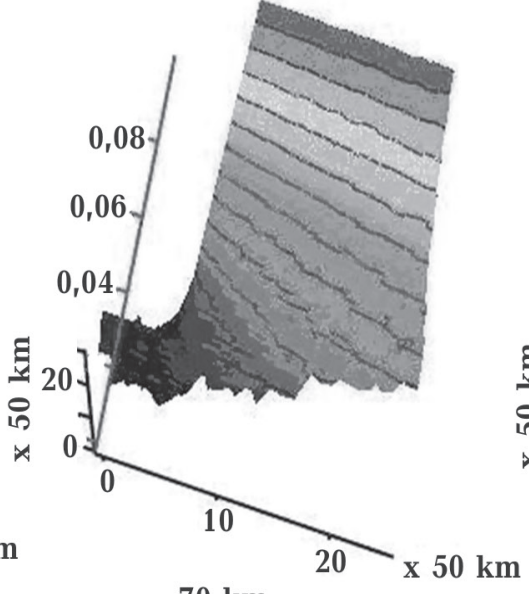

$70 \mathrm{~km}$

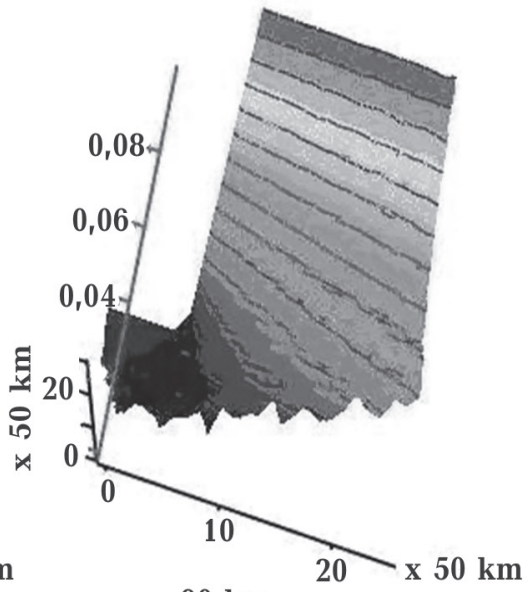

$90 \mathrm{~km}$

Odessa $t_{p}$

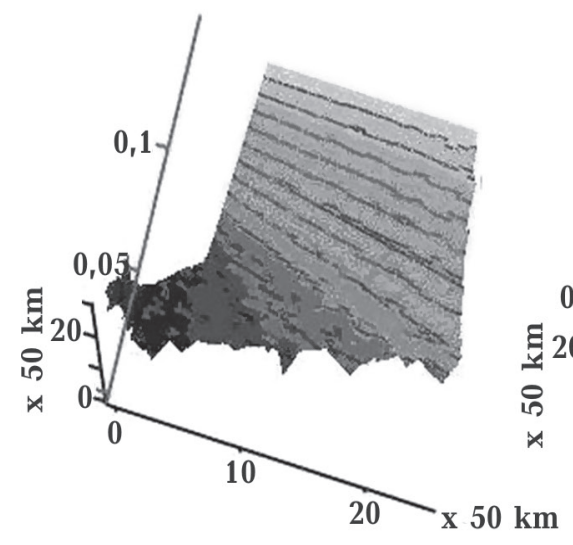

$50 \mathrm{~km}$

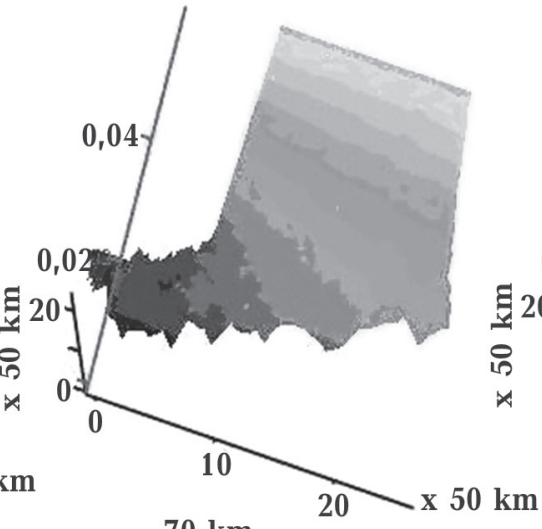

70 km

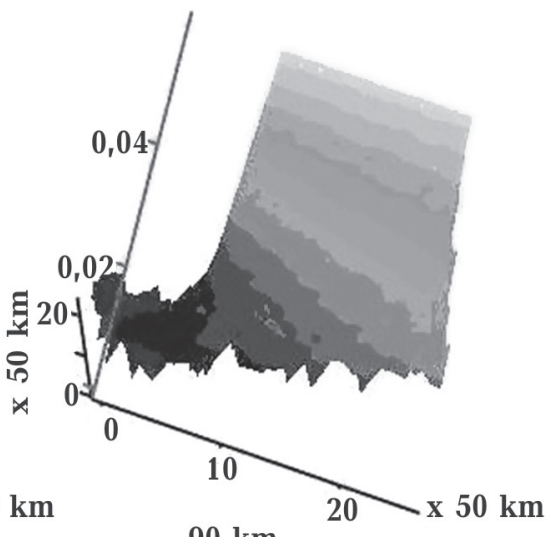

90 km

Poltava $t_{p}$

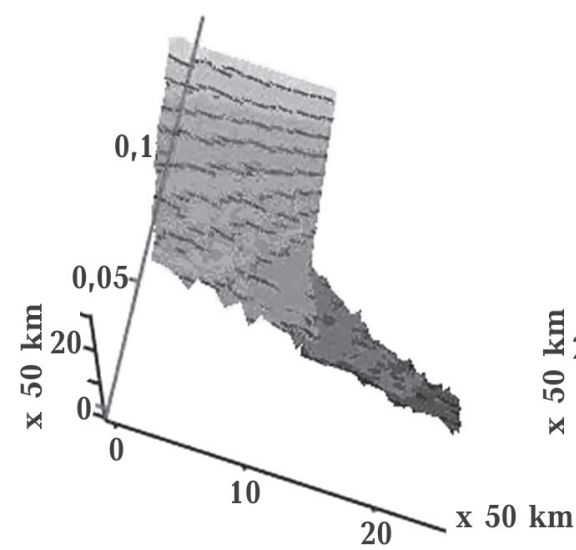

$50 \mathrm{~km}$

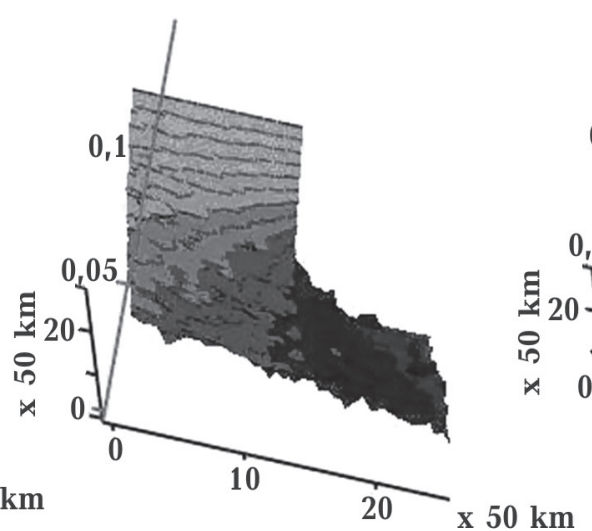

$70 \mathrm{~km}$

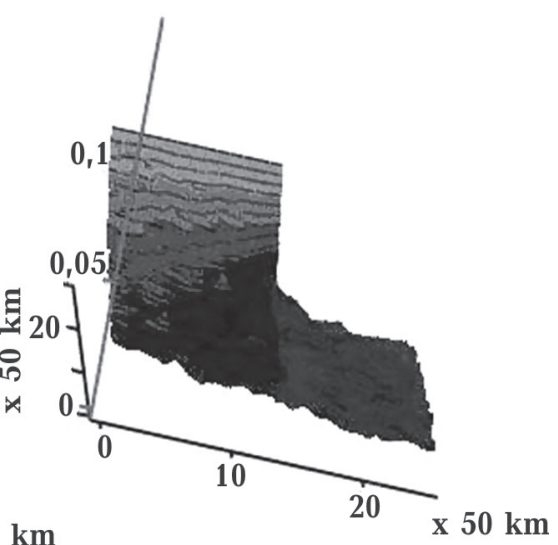

$90 \mathrm{~km}$

Fig. 6. 3D image of the velocity gradients of $\mathrm{P}$ and $\mathrm{S}$ seismic waves, obtained as a result of inverting the time curves, 


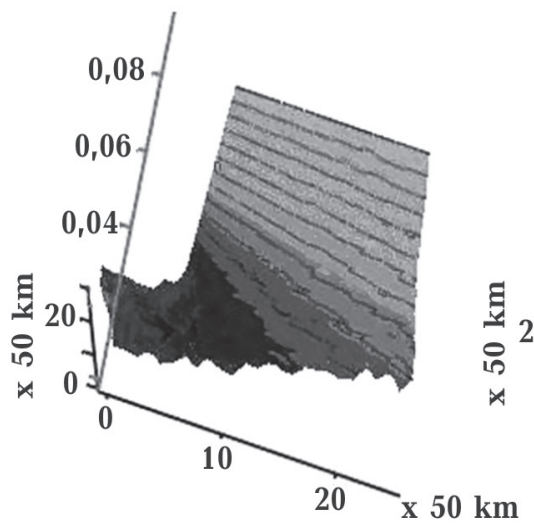

$50 \mathrm{~km}$

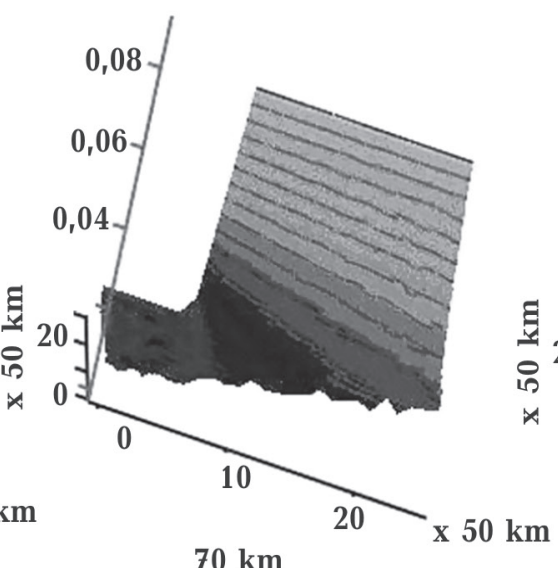

$70 \mathrm{~km}$

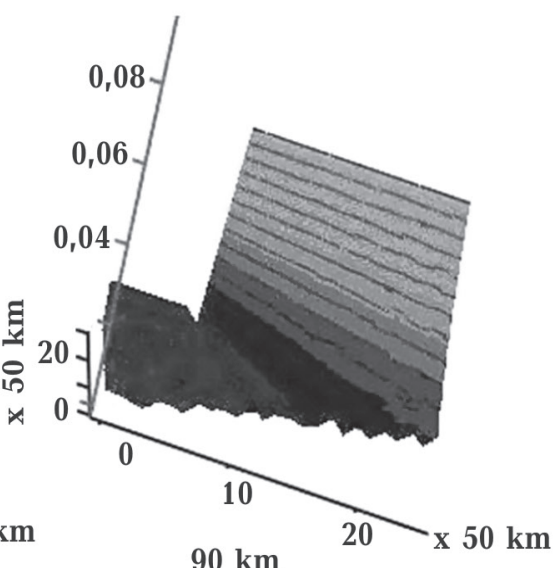

$90 \mathrm{~km}$

Odessa $t_{s}$

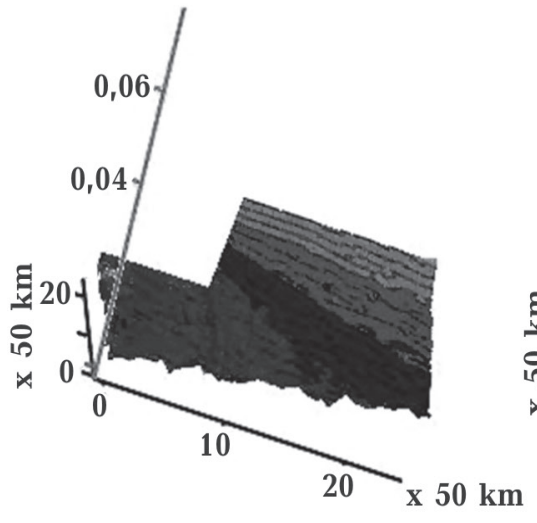

$50 \mathrm{~km}$

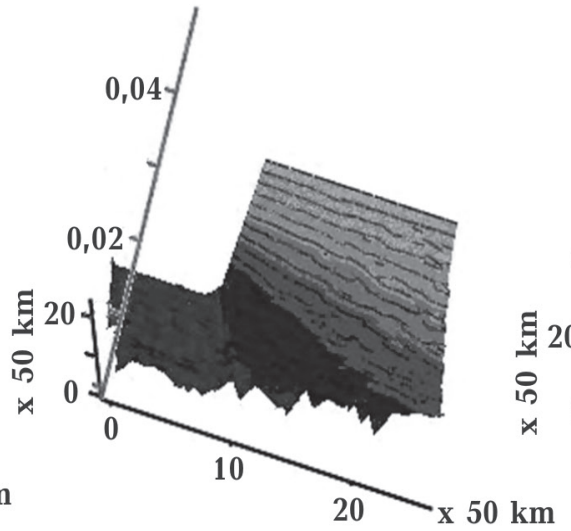

70 km

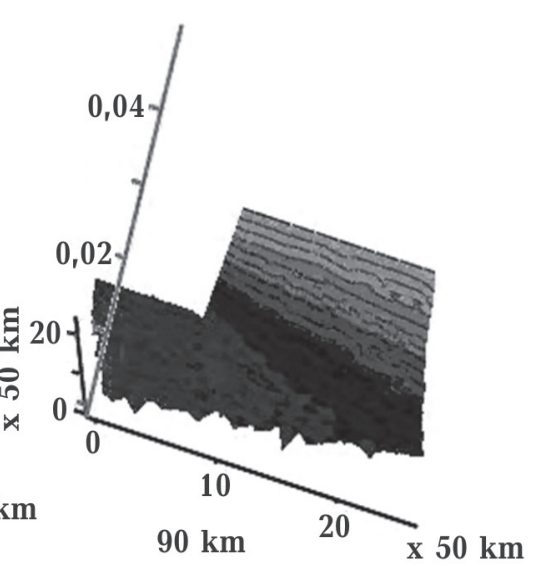

Poltava $\boldsymbol{t}_{\boldsymbol{s}}$

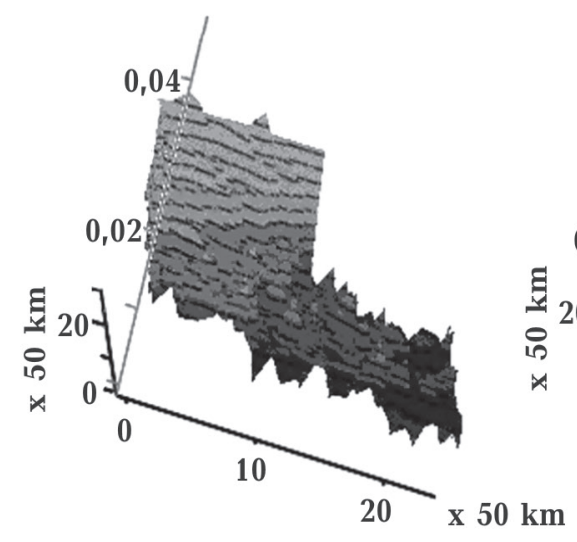

50 km

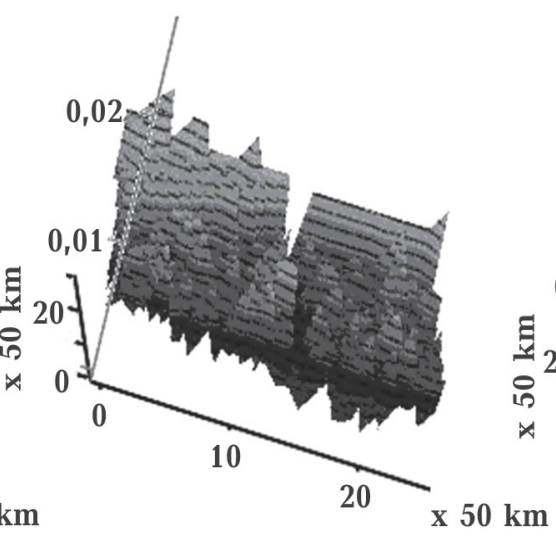

$70 \mathrm{~km}$

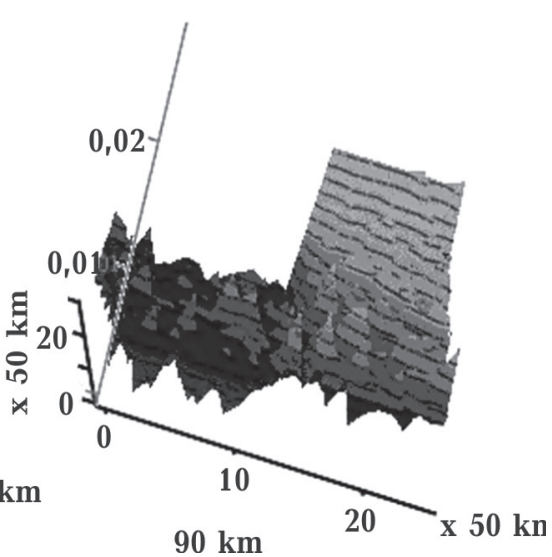

$90 \mathrm{~km}$

generated by the connectionist model of the arrival times of the phases, recorded by the network of seismic stations. 


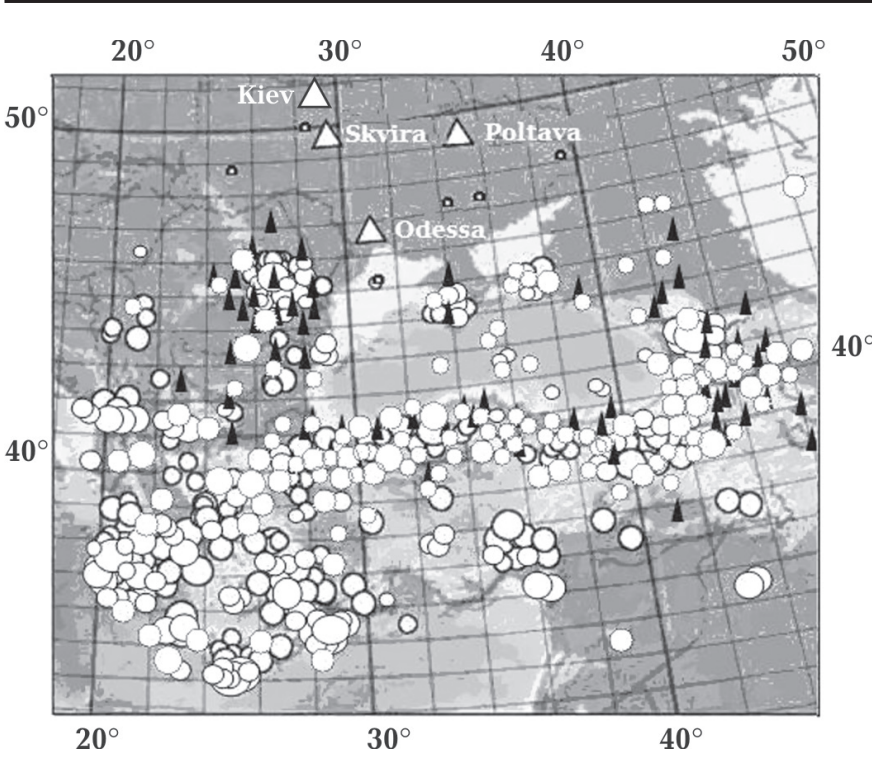

Fig. 7. Scheme of the region of data collection. Black triangles indicate the data used by international seismological centers.

node, the azimuth of the path and the length of the time curve, the coordinates of points of its beginning and end may be determined by the algorithm of the inverse geodesic problem. [Sjöberg, Shirazian, 2012; Поклад, 1988]. The elevation of the point above sea level was estimated by the value of a certain raster element, applied on the net region, and being the nearest to the node. The values of elevation were introduced by the GOOGLE-EARTH system, and their density was set not less than 4 per cell of the net region. The 9-dimensional neural model enables the simulation of the time curve along the paths, passing through the given node with different azimuths. This scheme for the case of one node is shown in Fig. 8.

The 9-dimensional model generalizes

The records of 4542 events in the area under study with drawing a high-quality information from international seismic centres ISC, NEIC, ORF were used for the results under consideration. Such sample, used as a learning one, enables the development of the connectionist model, representing the arrival times of seismic phases from a random shot point to a random point of recording the area under study.

Knowing the geographic coordinates of a the results of the 4-dimensional one, eliminating a «single-point referencing» to the concrete seismic station and enables the coverage of the space around the node, considered as a midpoint for the family, with the wished density of the path location.

Fig. 9 gives an example of varying the velocities of the $\mathrm{P}$ and $\mathrm{S}$ phases of seismic waves in the Black Sea area at the depth of $70 \mathrm{~km}$ as a mathematical expectation of the results of inverting $(5,6)$ the family of direct and in-
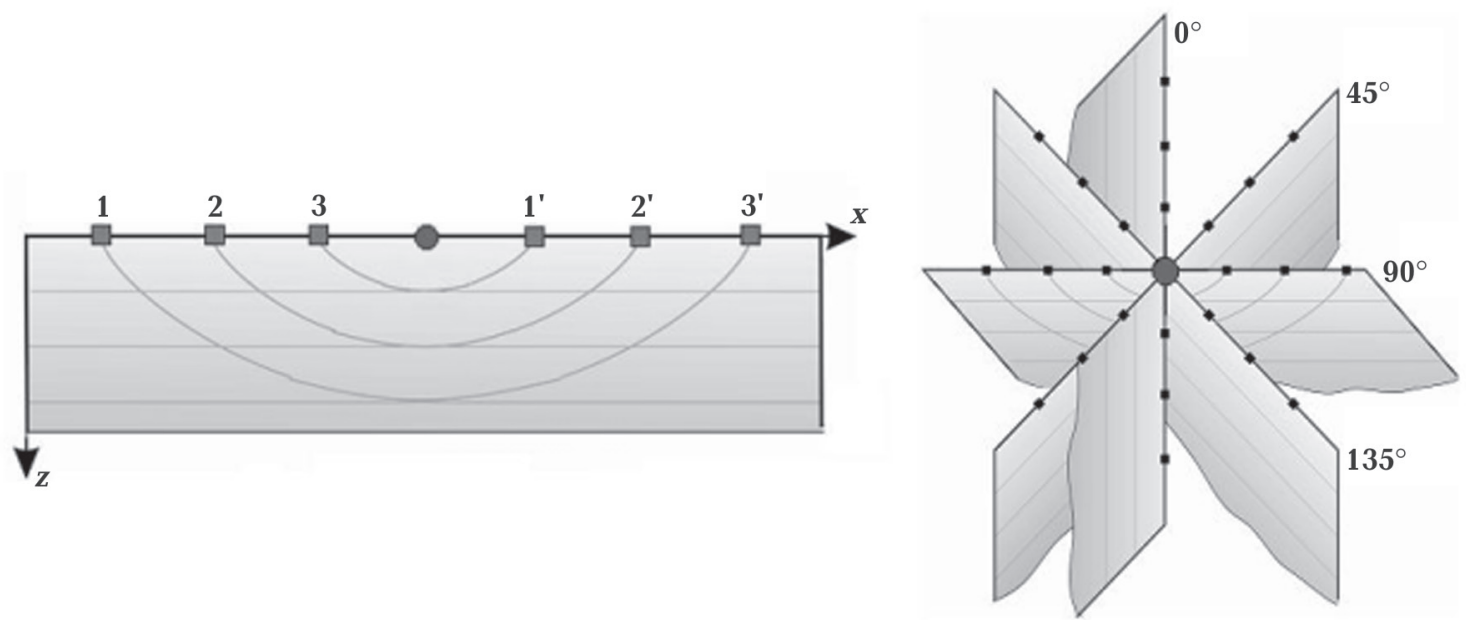

Fig. 8. Layout of the paths around the net node as a midpoint of the family of the time curves. 


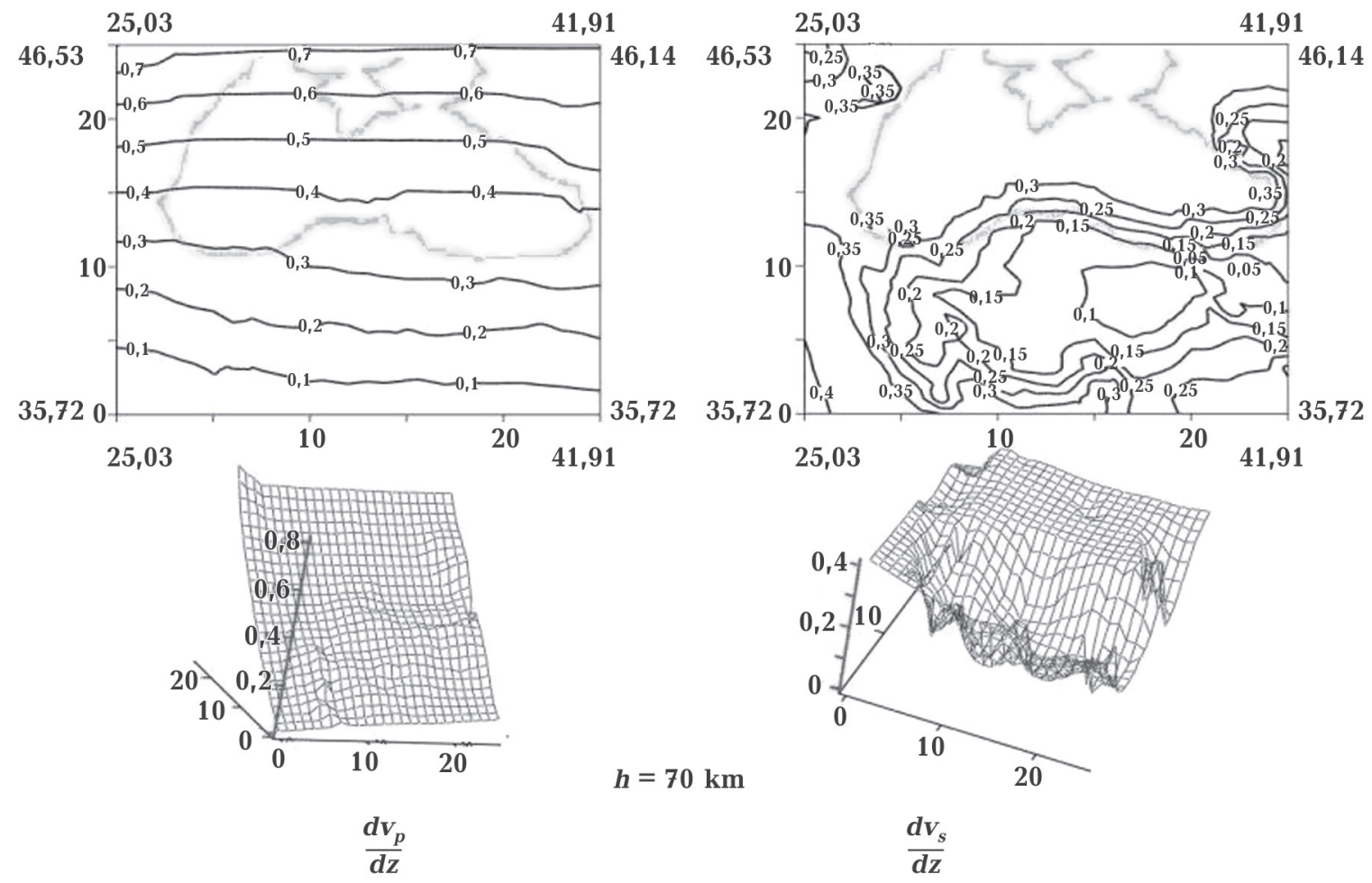

Fig. 9. Velocity gradient of the $\mathrm{P}$ and $\mathrm{S}$ phases of seismic waves within the area around the Black Sea at the depth of $70 \mathrm{~km}$.

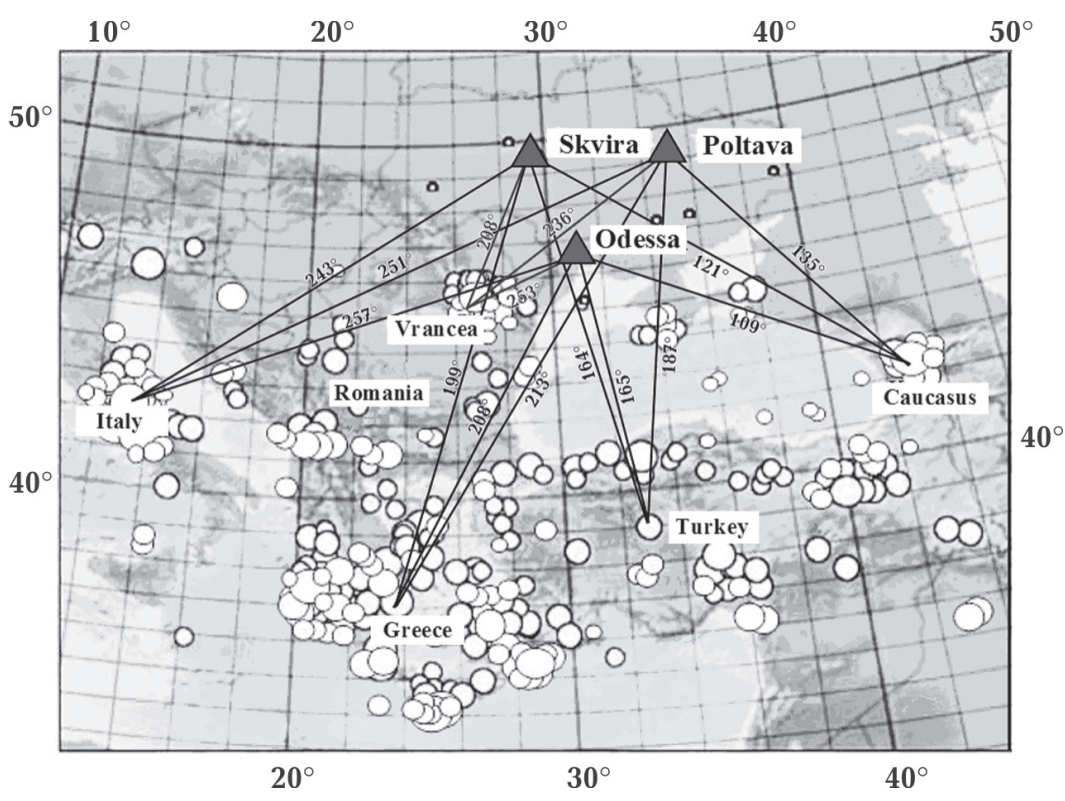

Fig. 10. The scheme of the directions of main seismically active cells of the radiation sources, recorded by seismic stations "Odessa», "Skvira», "Poltava», whereof the training sample is formed of the connectionist model of the propagation times of seismic waves. The digits designate the back azimuths of the radiation «centres» of five sectors of generating earthquakes for each s/s. verted time curves along 4 paths, passing with the spacing of $45^{\circ}$ through each node of the net region.

Estimates of the maximum depths of the ray penetration of the $P$ and $S$ waves, recorded by the network of seismic stations. The upto-date notions of the deep structure of the Earth contain the information about a high probability of the presence of the areas of velocity inversion in the crust and the upper mantle [Литосфера..., 1994; Гобаренко, Яновская, 2011], wherefore the conformity of the results of using the one-dimensional model of inverting a time curve $(5,6)$ lower these depths with the actual structure of the me- 

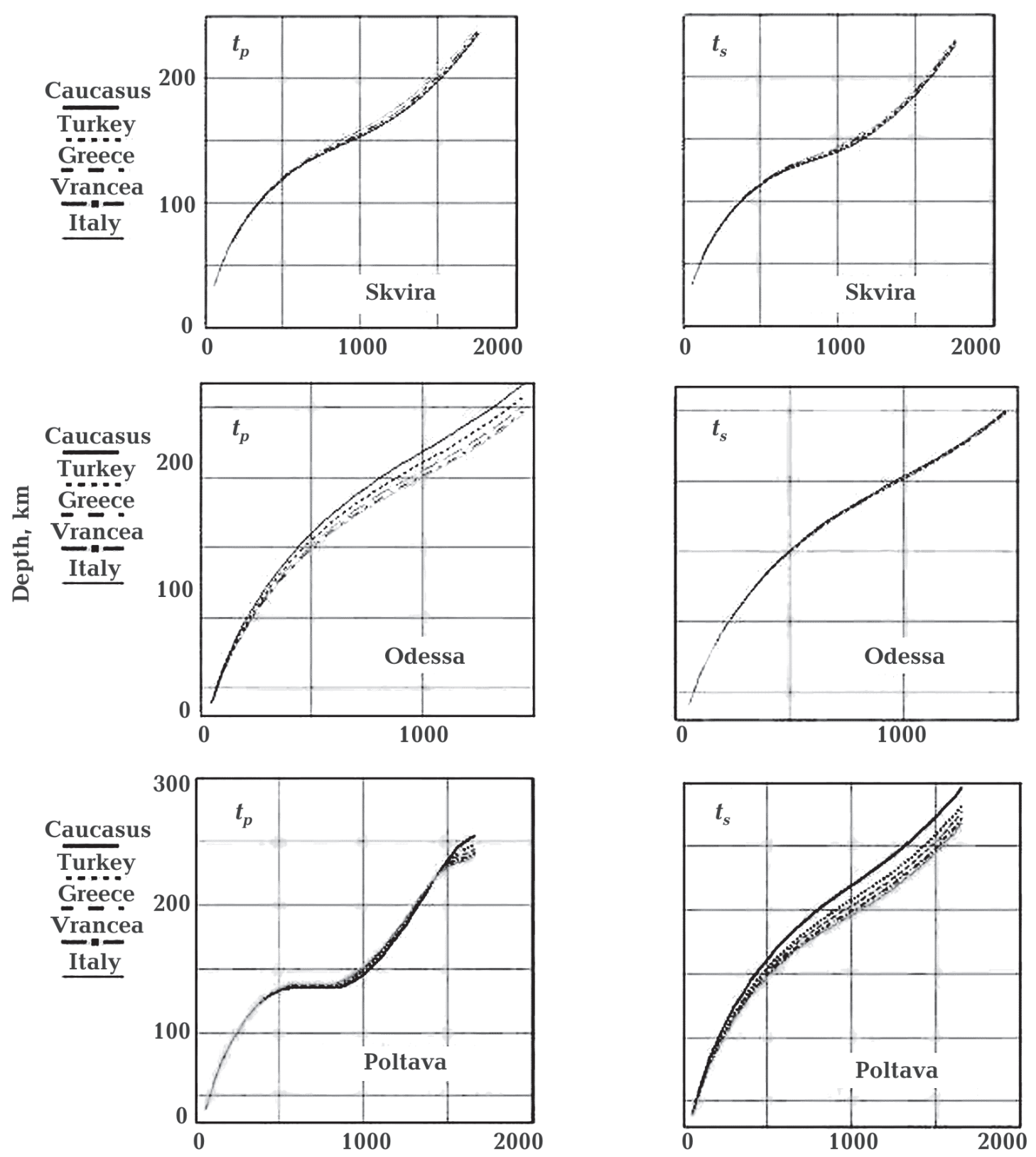

Epicentral distance, km

Fig. 11. The dependence of the maximum penetration depth rays $\mathrm{P}$ and $\mathrm{S}$ phase seismic waves from the epicentre distance depending on the direction of the source of excitation signal registered on seismic stations network.

dium may raise a doubt. The non-conformity of the $\mathrm{H}-\mathrm{W}$ model with the actual medium is contained in the requirement for the positivity of the velocity gradient with depth, that is in the ban of the "layers» with a reduced velocity - the H-W medium provides for the increase in the maximum depth of the ray penetration with the increase in the length of a time curve. The deviation from this law of nature may serve as a sign of breaking the condition $d v / d z>0$.

Pursuant to Fig. 10 is given the dependence of the depth of the ray penetration below on the direction of the arrival of a seismic signal 
from the Caucasus, Turkish, Mediterranean (Greece, Italy) sources of earthquakes and the Vrancea area, obtained in inverting the time curves, generated by the connectionist model for each of three seismic stations.

The figures show that the distortions in the curve of the growth in the depths of the ray maximum penetration are observed for all seismic stations and both phases, but the nature of these distortions is individual for each point of reception and, although in a less degree, but also for the azimuth of the arrival of a seismic wave. Such behaviour of rating the maximum depth requires a certain caution in using the model of the $\mathrm{H}-\mathrm{W}$ behaviour in this application in the given area. In spite of the limitation of the H-W model, its use attracts attention by its analytical maturity and direct output of results without any use of intermediate structures undergoing an iterative improvement.

Demonstrating the obtained results of using the inversion of the $\mathrm{H}-\mathrm{W}$ connectionist models of the time curves, the authors have not set sights on interpreting various behaviour scenarios of the simulated function with regard to the geologic structure of the concrete region under study. The point at issue is about the possibility and necessity to develop

\section{List of literature}

Гобаренко В. С., Яновская Т. Б. Скоростная структура верхних этажей мантии басейна Черного моря. Геофиз. журн. 2011. Т. 33. № 3. С. 62-74.

Аазаренко М. А., Герасименко О. А. Нейросетевое моделирование годографов сейсмических волн. Геофиз. журн. 2010. Т. 32. № 5. С. 126-141.

Аuтосфера Центральной и Восточной Европы: Молодые платформы и Альпийский складчатый пояс. Под ред. А. В. Чекунова. Киев: Наук. думка, 1994. 331 с.

Покıаg Г. Г. Геодезия: Учеб. Аля вузов Москва: НеАра, 1988. 304 с. the operating algorithms of the modern continually operating system for displaying the wave process within the geological medium in the form of a digital recording system and the image (imprint) of this process in the form of the matrix of interneuron connections in the completed iterative process of training a neural network.

In particular, engineering the connectionist model of the travel of seismic $\mathrm{P}$ and $\mathrm{S}$ waves and rating the accuracy of displaying and functioning the model in the real-time mode offer the opportunities of not only an on-line building and a further inversion of multidimensional time curves of seismic waves, as well within randomly set geographic coordinates of the epicentre of the earthquake focus and seismic stations, but also the forecast of its behaviour at «dead» distances by the limited number of records.

The geological interpretation of the obtained results, as well as the setting of the seismic potential of the active tectonic structures of the observation territory on the basis of neural networks, will get weightier with the development of the algorithm and software of the integral analysis of seismic and geological data.

Хайкин C. Нейронные сети: полный курс. Москва: Вильямс, 2008. 1103 с.

Chauvin Y., Rumelhart D. E., 1995. Back Propagation: Theory, Architectures, and Applications. Lawrence Erlbaum Associates, 564 p.

Lay T., Wallace T. C., 1995. Modern Global Seismology. San Diego: Academic. Press, 521 p.

Sjöberg L., Shirazian M., 2012. Solving the Direct and lnverse Geodetic Problems on the Ellipsoit by Numerical Integration. J. Surv. Eng. 138(1), 9-16. https://doi. org/10.1061/(ASCE)SU.1943-5428.0000061\#sthash. qIIieVw6.dpuf. 


\title{
Neural network modeling of Herglotz-Wiechert inversion of multiparametric travel-time curves of seismic waves
}

\author{
(․ Lazarenko, O. Herasymenko, 2017
}

Using artificial neural networks to solve a problem of plotting travel-time curves of seismic waves can create nonlinear travel-time model of $\mathrm{P}$ and $\mathrm{S}$ phases of seismic waves arrangement as a function of several arguments: source depth, magnitude, back azimuth and epicenter distance. Construction of three-dimensional travel-time relationships and their use for modeling of hadographs and their inversion are considered on examples of seismic records Ukrainian seismic stations. Examples of inversion locus within the model Herglotz-Wiechert and features of application of the model in a real environment for single seismic stations, and generalization for arbitrary coordinate of the source and the point of signal registration in the Black Sea region are given.

Key words: neural network, seismic waves propagation, training, the Herglots-Wiechert inversion, discrepancies, travel-time curves, velocity gradient.

\section{References}

Gobarenko V. S., Yanovskaya T. B., 2011. Velocity structure of the upper levels of the Black Sea mantle. Geofizicheskiy zhurnal 33(3), 62-74 (in Russian).

Lazarenko M. A., Gerasimenko O. A., 2010. Neural network modeling of the travel time curves of seismic waves. Geofizicheskiy zhurnal 32(5), 62-74 (in Russian).

Lithosphere of Central and Eastern Europe: Young platforms and the Alpine folded belt, 1994. Ed. A. V. Chekunov. Kiev: Naukova Dumka, 331 p. (in Russian).

Poklad G. G., 1988. Geodesy: Proc. For high schools .Moscow: Nedra, 304 p. (in Russian).
Khaykin S., 2008. Neural networks: a full course. Moscow: Williams, 1103 p. (in Russian).

Chauvin Y., Rumelhart D. E., 1995. Back Propagation: Theory, Architectures, and Applications. Lawrence Erlbaum Associates, 564 p.

Lay T., Wallace T. C., 1995. Modern Global Seismology. San Diego: Academic. Press, 521 p.

Sjöberg L., Shirazian M., 2012. Solving the Direct and lnverse Geodetic Problems on the Ellipsoit by Numerical Integration. J. Surv. Eng. 138(1), 9-16. https://doi.org/10.1061/(ASCE)SU.19435428.0000061\#sthash.qIIieVw6.dpuf. 